\title{
Creation of the World: Regulation of Development of Host Immunity by Microbiota from Birth Onwards
}

\author{
Ger T. Rijkers ${ }^{1,2^{*}}$, Ciska Lindelauf ${ }^{1}$, Wieke Kagenaar ${ }^{1}$, Nicole B. Rutten ${ }^{3^{*}}$ and Frans J. van Overveld \\ ${ }^{1}$ Department of Science, University College Roosevelt, Middelburg, The Netherlands \\ ${ }^{2}$ Laboratory for Medical Microbiology and Immunology, St Antonius Hospital, Nieuwegein, The Netherlands \\ ${ }^{3}$ Department of Pediatrics, St Antonius Hospital, Nieuwegein, The Netherlands
}

\begin{abstract}
Human fetal development takes place in the sterile environment of the uterus. The development Received: April 06, 2018 of the immune system starts as early as 8 weeks gestation. Directly after birth, in fact already during Accepted: June 28, 2018 the birth process, the newborn baby comes into contact with bacteria from the environment, and the Published: June 30, 2018 gastrointestinal tract becomes colonized with microbiota. This also marks the first contacts of the (mucosal) immune system with microbial antigens. The early exposure to a variety of microbial stimuli regulates the balanced development of the neonatal immune system. On the other hand, the activity of the immune stem also shapes the composition and functionality of the gut microbiota. The cellular and molecular mechanisms underlying these interactions will be discussed in this review, as well as the implications for maintenance of homeostasis and prevention of (immune mediated) diseases.
\end{abstract}

Publication History:

\section{Keywords:}

Neonatal, Immune system, Microbiota, Probiotics, Regulatory T cells, IgA

\section{Introduction}

The number of bacteria inhabiting the human body is estimated to be approximately ten times larger than the number of human body cells. It should be mentioned however that this estimate recently has been challenged [1]. The majority of these micro-organisms are found in the gastrointestinal tract, which comprises approximately 1014 bacteria [2-4]. This bacterial population is referred to as the gut microbiota and weighs more than $1.5 \mathrm{~kg}$. Because the human host and the gut microbiota are totally dependent on each other, collectively they are termed a 'super organism' [5]. The gut microbiota can be considered an 'acquired' organ, because intestinal colonization starts immediately after birth and evolves as we grow. This process could be envisioned as the creation of the (microbial) world in the intestines (Figure 1). The microbiota constitutes an ecologically dynamic community with a number of essential functions for the human host. These include digestion of food components, providing nutrients and vitamins, regulation of intestinal development, maturation and regulation of the immune system, and more, all contributing to overall health [6,7]. In total, 2172 bacterial species have been identified in the human gut (Figure 2) [8], but one individual harbors around 160 different species [9]. Until the 1990s, knowledge of the gut microbiota was limited because conventional culture was the only technique to characterize its composition. However, it is estimated that at least 20 to $60 \%$ of the bacteria is uncultivable, resulting in an underestimation of gut microbiota diversity [10]. The introduction of culture-independent molecular and high-throughput approaches enabled phylogenetic investigations and quantification of the bacterial community, thereby refining the original perspective on composition and dynamic changes of the gut microbiota. These techniques moreover advanced our insights into the impact of host and environmental factors on bacterial community structure and dynamics [11].

One of the most exciting developments in recent years in the biomedical sciences has been the understanding that the intestinal microbiota strongly affects human physiology, by elucidating the mechanisms underlying the associations between gut microbiota health and disease [12-14]. The increase in the number of publications on the human microbiota has been exponential in the last few years and continues to grow (Figure 3). The outburst of discoveries in the microbiome field in the course of the last five to six years has changed our perspective on human biology, both in terms of health and disease.
This manuscript deals with the development of the intestinal microbiota in infancy. It includes the study of the effects of probiotics in early childhood on the composition and functionality of infant microbiota with a focus on the interaction between gut microbiota and development of the neonatal immune system. As search strategy of this review we searched Pubmed (https://www.ncbi.nlm.nih.gov/ pubmed/) and Web of Science (http://apps.webofknowledge.com) using the keywords microbiota in combination with development, infant, childhood, as well as immune system and immunity. No restriction on publication year was applied and for review articles the most recent ones were included.

\section{Origin and Definitions}

The potential association between the composition of human gut microbiota and the development of disease was proposed already by Metchnikoff in the early 20 th century. He hypothesized that replacing or diminishing 'putrefactive' bacteria in the gut with lactic acid bacteria could normalize bowel health and prolong life $[15,16]$. Joshua Lederberg, a Nobel prize winning American molecular biologist, known for his work in microbial genetics, emphasized the importance of the intestinal bacterial population and introduced the overarching term 'microbiome', 'to signify the ecological community of commensal, symbiotic, and pathogenic microorganisms that literally share our body space'[17]. Sometimes the term 'microbiome' is used interchangeably with the term 'microbiota' [18]. The microbiome is the collection of genomes of all microbes that live inside and on the human body (bacteria, but also bacteriophages, fungi, protozoa and viruses). The microbiota is the ecological community of commensal, symbiotic and "Corresponding Author: Prof. Ger T. Rijkers, Department of Sciences, University College Roosevelt, P.O. Box 944330 AB Middelburg, The Netherlands, Tel: +31 (0)118 655 500, Fax: +31 (0)118 655 508; E-mail: g.rijkers@ucr.nl

"Corresponding Author: Dr. Nicole B. Rutten, Department of General Practice, University of Groningen, University Medical Center Groningen, Groningen, The Netherlands; E-mail: b.rutten@maastrichtuniversity.nl

Citation: Rijkers GT, Lindelauf C, Kagenaar W, Rutten NB, van Overveld FJ, et al. (2018) Creation of the World: Regulation of Development of Host Immunity by Microbiota from Birth Onwards. Int J Clin Nutr Diet 4: 132. doi: https://doi. org/10.15344/2456-8171/2018/132

Copyright: (c) 2018 Rijkers et al. This is an open-access article distributed under the terms of the Creative Commons Attribution License, which permits unrestricted use, distribution, and reproduction in any medium, provided the original author and source are credited. 
Citation: Rijkers GT, Lindelauf C, Kagenaar W, Rutten NB, van Overveld FJ, et al. (2018) Creation of the World: Regulation of Development of Host Immunity by Microbiota from Birth Onwards. Int J Clin Nutr Diet 4: 132. doi: https://doi.org/10.15344/2456-8171/2018/132

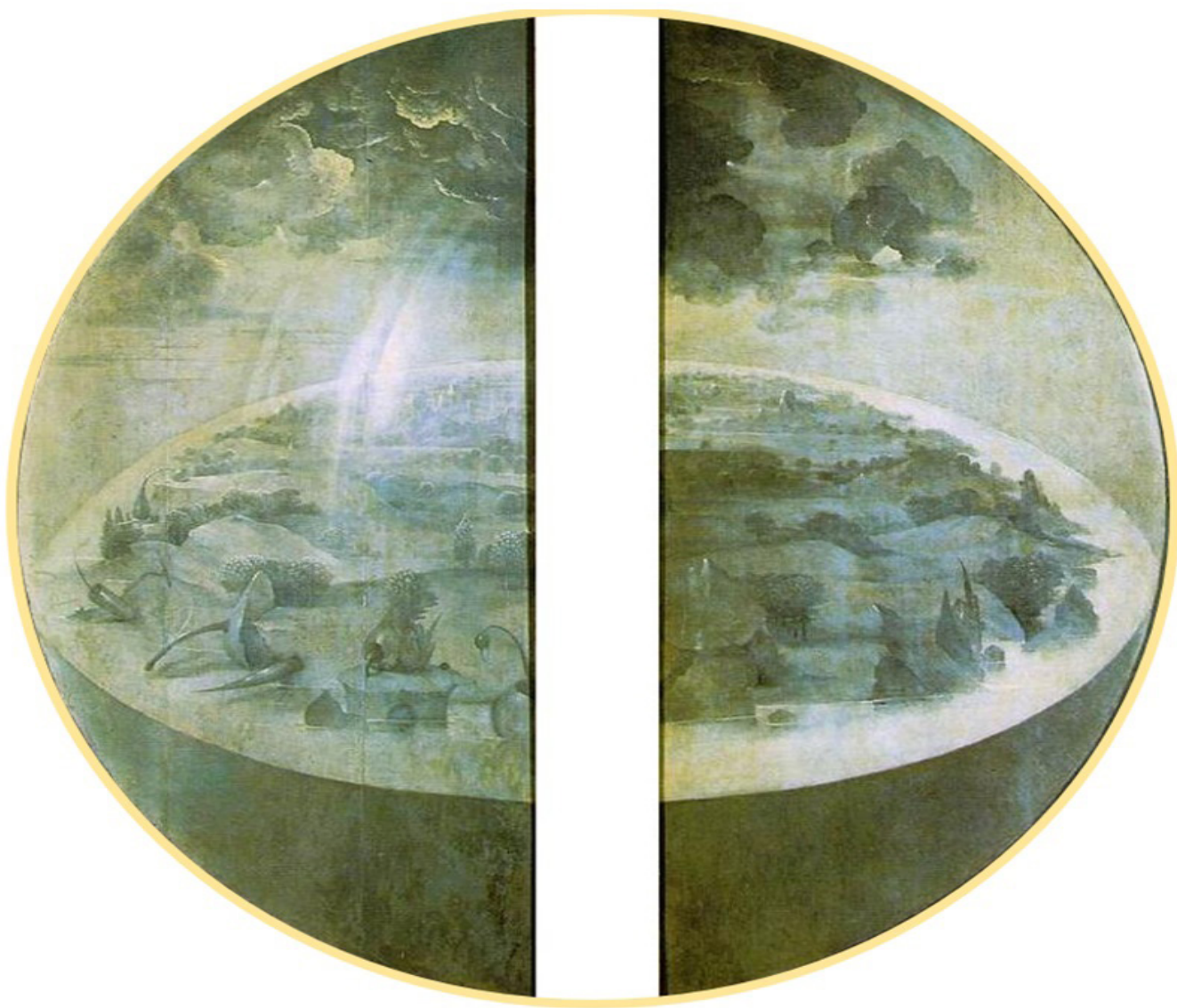

Figure 1: The Creation of the World painted by Jheronimus Bosch in 1514 on the reverse side of The Garden of Earthly Delights. Museo El Prado, Madrid, Spain. Source Wikimedia Commons.

\section{-Firmicutes}

909909909999090

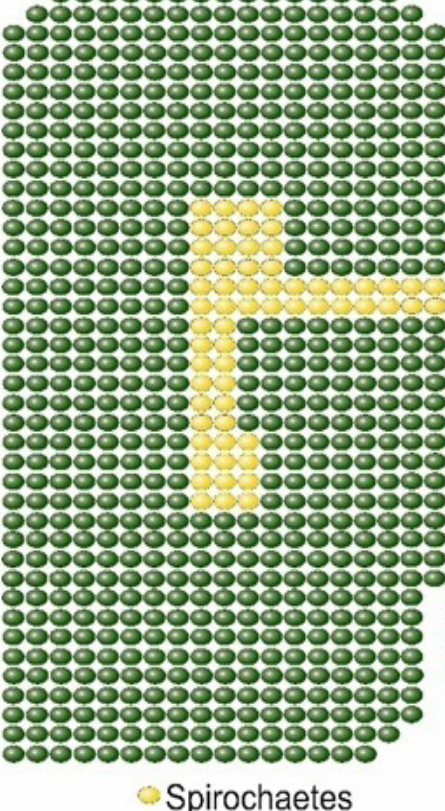

- Tenericutes

-Actinobacteria
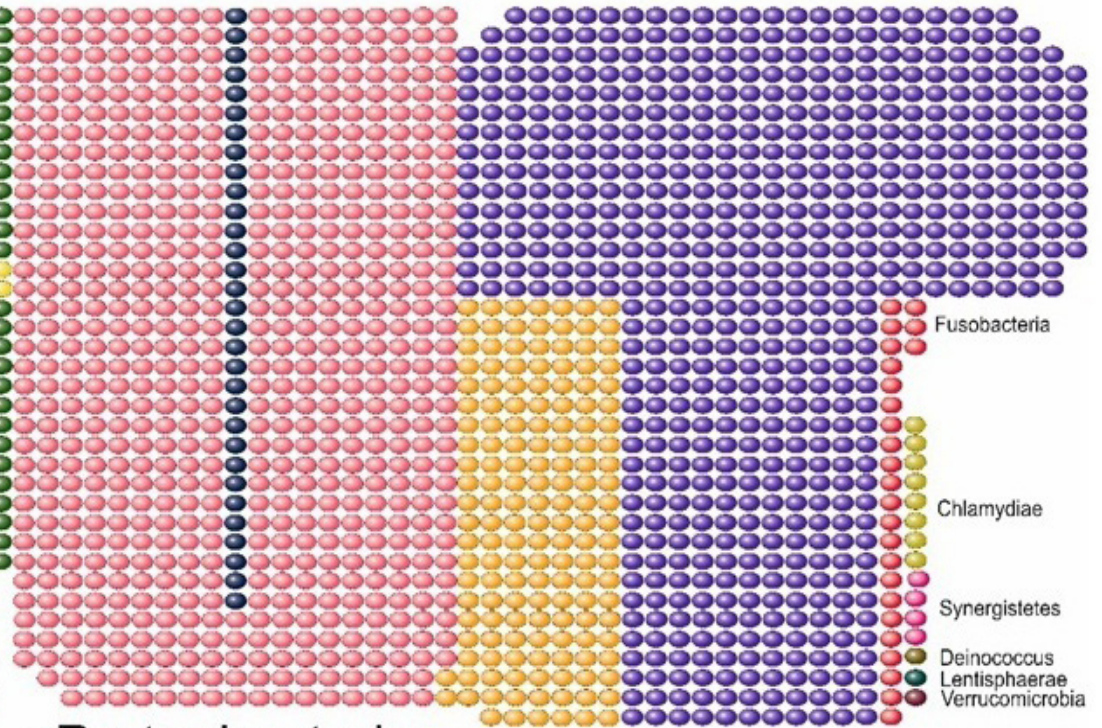

-Proteobacteria - Bacteriodetes

Figure 2: Relative proportions of the major bacterial phyla in the human intestine. 


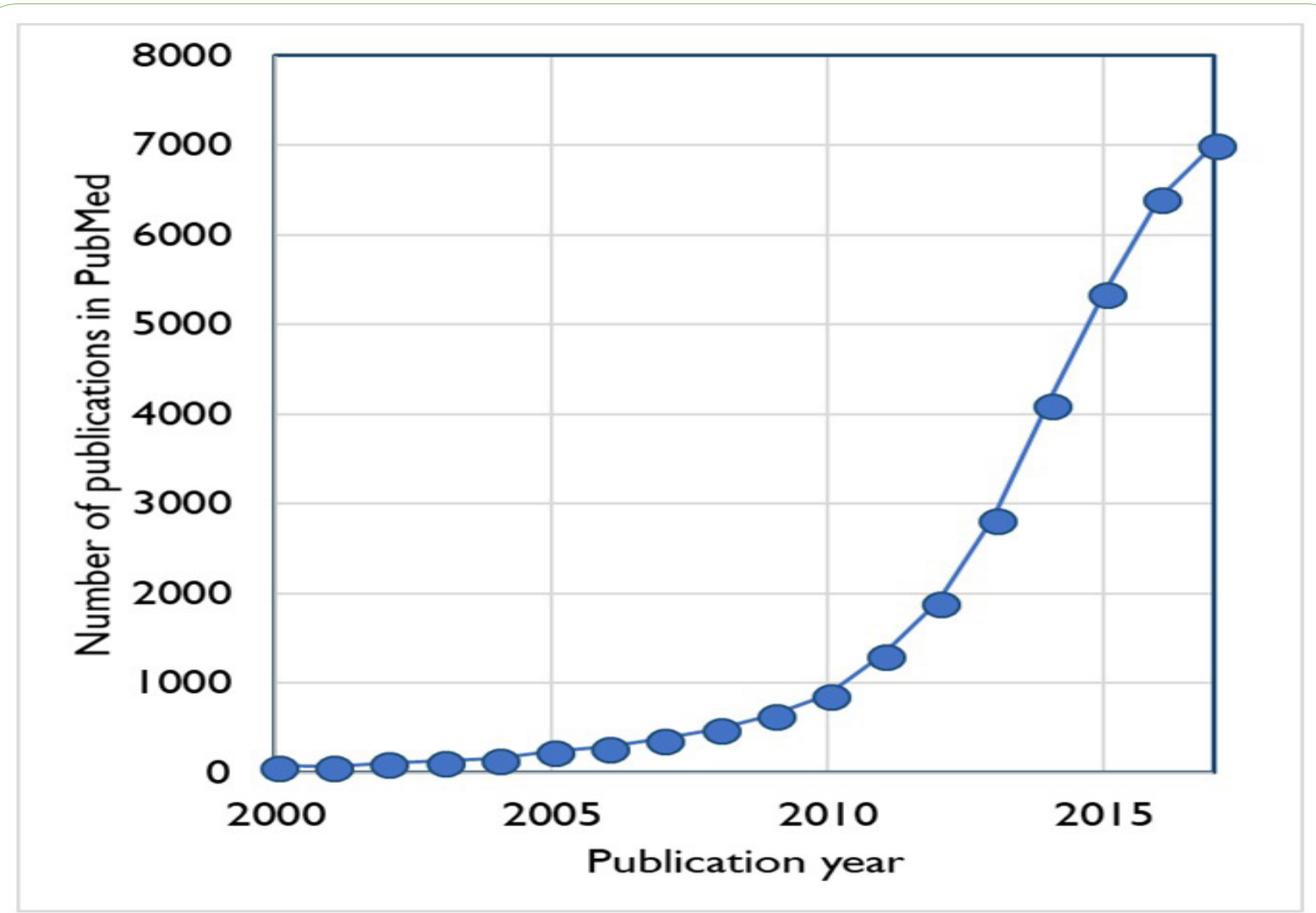

Figure 3: Increase in the number of scientific publications in PubMed using the search term "microbiota”.

pathogenic microorganisms that resides in a previously established environment [12]. This microbial community was previously termed gut flora, a term which should be discouraged because it would suggest that bacteria belong to the plant kingdom. Description of the functionality of the gut microbiota can be done by investigating the collective assortment of metabolites present in a stool sample (the fecal metabolome), referred to as 'metabolomics'; by studying the total transcribed RNA, referred to as 'metatranscriptomics', and by focusing on protein levels, called 'metaproteomics.' 'Metagenomics' (also known as environmental genomics or community genomics) is the study of the metagenome, i.e. the collective community of genomes from a particular ecosystem (in this case, the gut). When only genes are assessed, a marker gene study is performed $[4,19,20]$. It is estimated that the human gut metagenome consists of 9,879,896 genes [21], a dazzling number when compared to the 18,877 human genes [22]

\section{Classification and Composition of Gut Microbiota}

All life on earth, from microbes to larger organisms, including man, has gone through a similar biochemical evolution. Back in 1977, Carl Woese performed comparative studies of rRNA sequences and underpinned the basis for a universal phylogeny. He outlined a universal sequence-based tree of life, with three phylogenetic domains: Archaea, Bacteria and Eukarya [23]. Nowadays, this three-domain model is grounded by further information on gene sequence and on biochemical correlations [24]. Over the past decades, the rRNA gene sequences have been a major advancement for microbial identification. Most bacterial species isolated from the human gut (93.5\%) are members of four bacterial phyla: Firmicutes, Proteobacteria, Actinobacteria, and Bacteroidetes (see also Figure 2) [8]. The Firmicutes are mainly represented by the genera Clostridium,
Faecalibacterium, Blautia, Ruminococcus, and Lactobacillus, and the Bacteroidetes including Bacteroides and Prevotella $[25,26]$. Other phyla such as Proteobacteria (Gammaproteo bacteria with Enterobacteriaceae), Actinobacteria (Bifidobacterium), Fusobacteria and Verrucomicrobia (Akkermansia) are present in lower abundance but also have a significant influence on the total microbial configuration $[8,27]$.

\section{Development of the Intestinal Microbiota}

From birth onwards, the infant intestine becomes increasingly colonized with a wide variety of microorganisms. This would imply, and that is the general consensus, that during the fetal period the intestine is sterile. Lately this view has been challenged and the concept of a fetal microbiome has been put forward. Is there something like a fetal microbiome, and if so, where does it come from? Sensitive molecular methods would point towards the existence of a placental microbiome, resembling the oral microbiome [28]. Also amniotic fluid and meconium have been shown to contain bacterial DNA $[29,30]$. Critics state that the placenta microbiome is indistinguishable from contamination during DNA isolation and this issue certainly is not resolved [31].

Whether or not the intestines are sterile at the moment of birth, the gastrointestinal tract will become exposed to bacteria from the environment already during the birth process or immediately after birth. The classical early colonizers of the infant gut are facultative anaerobes of the phylum Proteobacteria, such as Escherichia coli and other Enterobacteriaceae. These organisms pave the way for strictly anaerobic bacteria such as Bifidobacterium, Clostridium, and Bacteroides, and sometimes Ruminococcus, by depleting the 
Citation: Rijkers GT, Lindelauf C, Kagenaar W, Rutten NB, van Overveld FJ, et al. (2018) Creation of the World: Regulation of Development of Host Immunity by Microbiota from Birth Onwards. Int J Clin Nutr Diet 4: 132. doi: https://doi.org/10.15344/2456-8171/2018/132

Page 4 of 10

initially available oxygen in a matter of days. The rapid colonization by commensal bacteria has great impact for the development of the (mucosal) immune response of the infant. It leads to a balanced development of the various components of the mucosal immune system and induces tolerance to those bacteria. The infant gastrointestinal community is characterized by low stability, limited bacterial richness and great inter-individual variation [32,33]. During the period prior to weaning the microbiome can display large shifts in the abundances of bacterial taxa $[34,35]$. Subsequently, the intestinal microbiota of the infant slowly develops and matures. Weaning results in a shift towards the bacterial group's characteristic of the adult microbiota [36]. The microbial community is thought to reach an adult-like composition

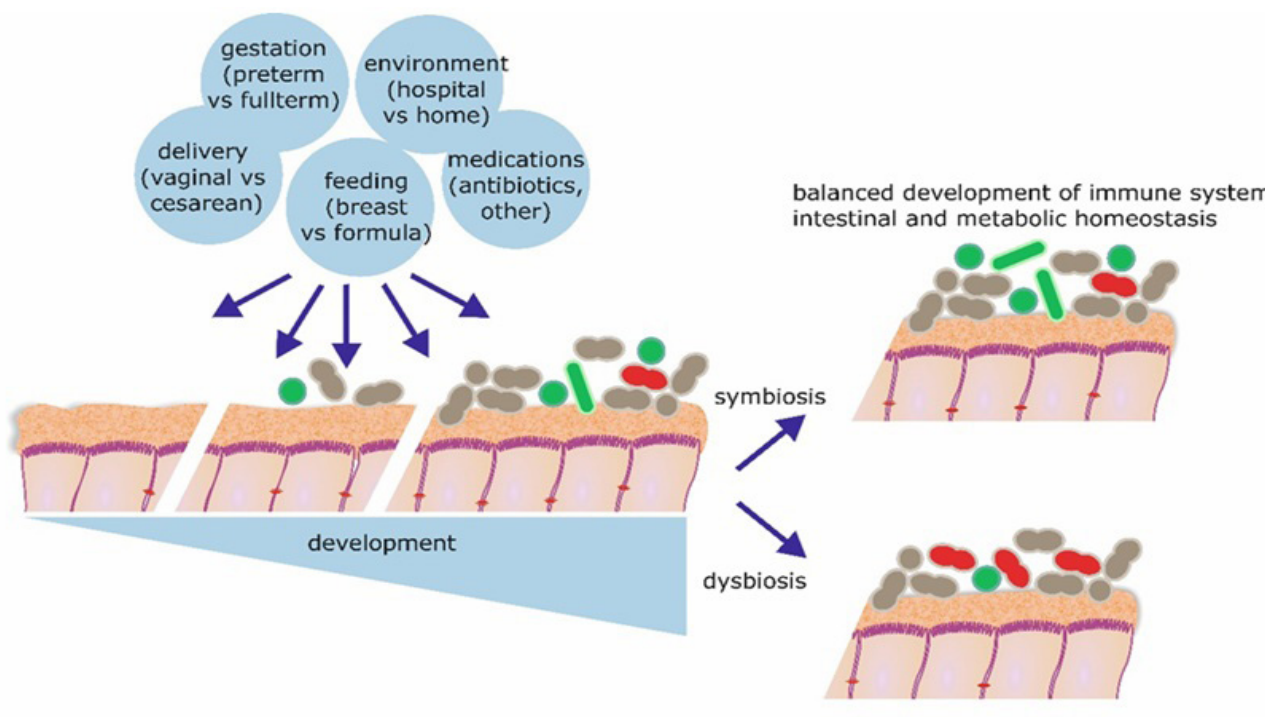

immune mediated diseases (allergic, autoimmune) gastrointestinal diseases (NEC, IBD) metabolic diseases (diabetes, obesity)

Figure 4: Factors influencing gut microbiota development in early infancy and conception of possible programming mechanisms by the intestinal microbiota. NEC = necrotizing enterocolitis; IBD = inflammatory bowel disease. Based upon references [18,75].

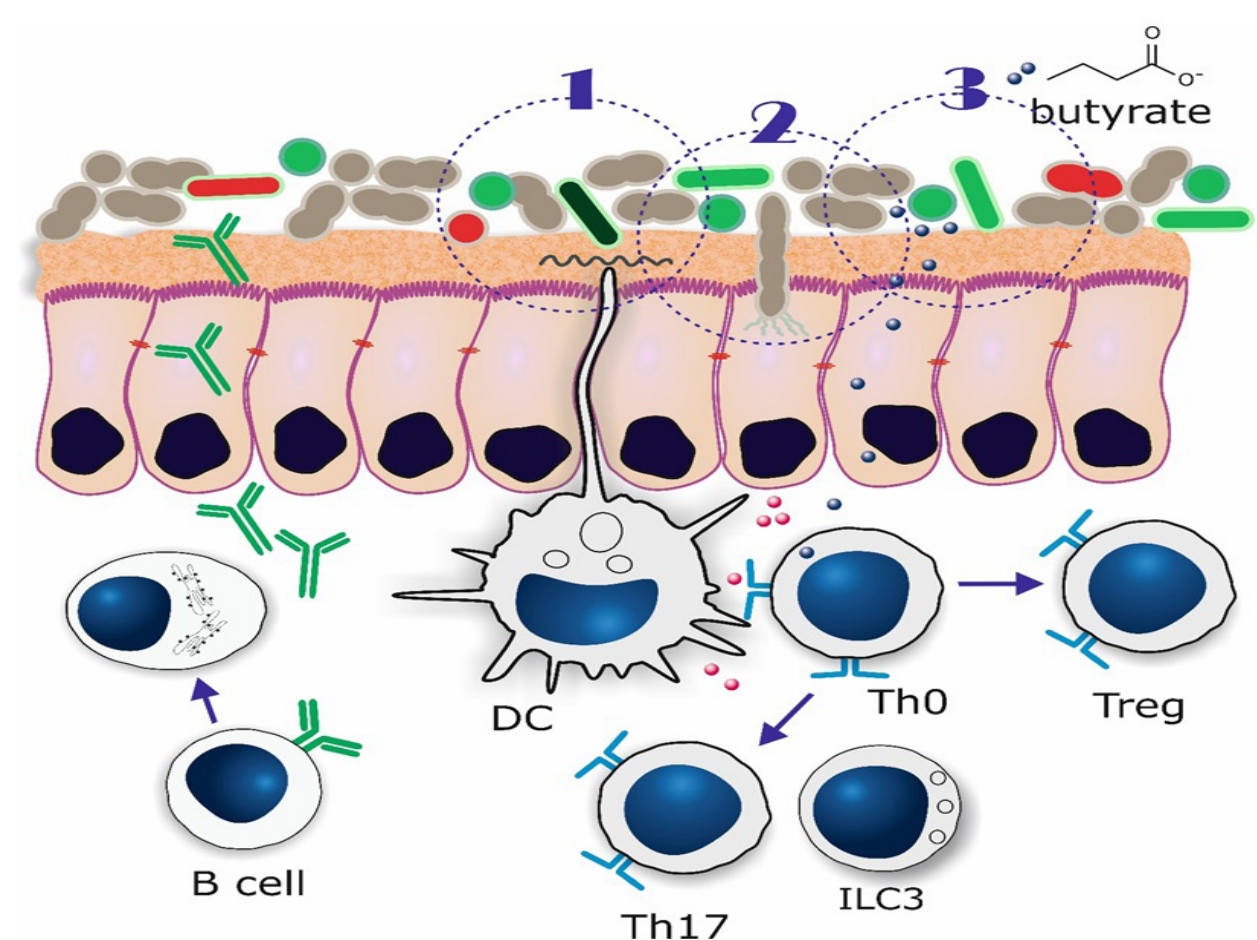

Figure 5: Interaction between gut microbiota and the mucosal immune system. Cellular processes depicted in the hatched circles 1,2, and 3, are explained in the text. Cells of the mucosal immune system are indicated as follows: dendritic cell (DC), undifferentiated T helper lymphocyte (Th0), regulatory T helper lymphocyte (Treg), type 17 T helper lymphocytes (Th17), type 3 innate lymphoid cell (ILC3), and B lymphocyte (B cell). 
around three years of age [12,34]. Other literature however indicates that the evolvement into adult-like microbiota may continue beyond that age [37-39]. Which bacteria should be represented (quality as well as quantity) in a 'healthy' or 'normal' intestinal microbiota has not been clearly defined yet.

Recent literature suggests a broad core microbiota in adults with high variation in species, diversity and genetic functions between individuals, although the main microbial gene functions may be maintained in almost every individual [40-44].

\section{Genetic and Environmental Factors Influencing Development of the Intestinal Microbiota}

A wide range of factors, genetic and environmental, can influence the diversity and composition of the intestinal microbiota and its establishment (Figure 4). In the first few hours of life, the mother's vaginal and fecal bacterial populations are usually the most important source of inoculum. Moreover, skin microbiota of parents and siblings, bacteria from breast milk, and bacteria from the environment are sources of strains colonizing the gut in early life $[3,43,45]$. Mode of delivery, gestational age and feeding mode especially affect the infant's microbiota composition [46-49]. Besides, prescription of antibiotics in early life and supplementation with prebiotics or probiotics can have a direct and major effect on the development of the intestinal microbiota $[47,50,51]$.

Generally, the mode of delivery is the most influencing factor for microbiota development. Bifidobacterium species, known as beneficial species for the host, dominate the relatively simply composited microbiota of full-term vaginally-delivered infants within the first two weeks of life. Prominent genera are also Lactobacillus, Prevotella, Escherichia and Bacteroides, including a bacterial community that represents the mother's vaginal and intestinal microbiota [52,53]. Caesarean-delivered infants have a reduced number of Bifidobacterium; Staphylococcus, Corynebacterium, and Propionibacterium are dominating bacterial species in their microbiota which shows less resemblance to their mother's, as compared to vaginally delivered infants $[52,54,55]$. Another significant factor which influences microbiota composition is feeding type. The microbiota of breast-fed neonates is dominated by the genera Bifidobacterium and Ruminococcus. Formula-fed neonates have a more complex composition compared with breast-fed neonates and harbor a diverse microbiota including Enterobacteriaceae, Enterococcus and Bacteroides, as well as Bifidobacterium and Atopobium [46,56,57].

There is an overwhelming amount of evidence that exposure to antibiotics in early life, which has become common in modern obstetric and neonatal practice, is associated with profound effects on the neonatal gut microbiota composition. In general, antibiotic treatment leads to a decrease in the microbial diversity [58]. Overgrowth of Enterococci and arrested growth of Bifidobacterium in term infants exposed to antibiotics in the first week of life have been described [50,60-62]. Antibiotic exposure at the beginning of life can modify the course of bacterial infections and is associated with development of atopic disease [63-66] and with other immune mediated diseases $[67,68]$ as well as obesity [69].

Information on the role of genetic factors which affect the composition of the intestinal microbiome comes from studies of monozygotic and dizygotic twins and studies in humans where specific microbiota profiles are associated with subjects that have mutations at specific genetic loci. The data show that the microbiome is shared among family members, because individuals from the same family (twin pairs, or twins and their mother) have a more similar microbiota than unrelated individuals [70-72]. Despite the wide variation of shared microbial genes among individuals, an extensive, identifiable human 'core microbiome' at the gene level could be identified and deviations from this core were associated with different physiological states [42]. An increasing number of genes/molecules (such as the genes of the class 2 major histocompatibility complex (MHC)) is found to be associated with specific microbial compositions and detection and monitoring of the intestinal lumen by the mucosal immune system of the gut [73].

Microbial colonization of the intestine plays an important role in the postnatal development of the gastrointestinal system [74], thereby influencing host metabolism and disease development [18,20,75-77]. Bacteria form a complex ecological community that can modulate the expression of genes involved in several important intestinal functions. The community influences normal physiology and susceptibility to disease through collective metabolic activities and interactions, including nutrient absorption, mucosal barrier strengthening, xenobiotic metabolism, angiogenesis and postnatal intestinal development. Other functions of gut bacteria are the involvement in the metabolism of otherwise indigestible carbohydrates and the production of essential metabolites such as vitamin $\mathrm{K}$ [78-82].

\section{Impact of Gut Microbiota on Development of the Immune System}

The development of the immune system starts already during the fetal period. After 8 weeks of gestation the first B lymphocytes can be detected in the fetal liver. Progenitors of T lymphocytes start migrating to the thymus anlage by weeks 8 to 9 . B lymphocytes are detectable in fetal blood circulation by 12 weeks of gestation, T lymphocytes 3-4 weeks later [83]. The functional immune repertoire further develops during fetal life, but is not challenged because of the sterile environment [84-87].

The function of the mucosal immune system is to prevent pathogenic micro-organisms from the environment (in the context of the present discussion: from the gut) to invade the body. As outlined above, immediately after birth the gastrointestinal tract becomes colonized with bacteria and other micro-organisms.

The microbiota that colonizes the neonatal gastrointestinal tract is of utmost importance for growth and maturation of the various cellular components of the intestines itself, but certainly also for the regulated development of both the mucosal immune system of the gut as well as the systemic immune system [88]. This is demonstrated by (severe) deficiency of various types of immune cell types and organized lymphoid tissue in germ-free animals: secondary lymphoid organs such as mesenteric lymph nodes and Peyer's patches are smaller and fewer in number and have a poorly organized structure. $\mathrm{T}$ and Blymphocytes are reduced in numbers [88]. The gut microbiota also modulates the development and functionality of the innate immune system lining the gastrointestinal tract [89-91].

It would be an immense, if not impossible task, for the immune system to eliminate all micro-organisms from the gut. The 
Citation: Rijkers GT, Lindelauf C, Kagenaar W, Rutten NB, van Overveld FJ, et al. (2018) Creation of the World: Regulation of Development of Host Immunity by Microbiota from Birth Onwards. Int J Clin Nutr Diet 4: 132. doi: https://doi.org/10.15344/2456-8171/2018/132

Page 6 of 10

immune system therefore is programmed and matures in such a way that resident, non-pathogenic micro-organisms are tolerated and compartmentalized [92]. Induction of tolerance to resident microbiota is induced immediately after birth and involves Toll-like receptor (TLR) signaling via secretory leukocyte protease inhibitor proteins $[93,94]$.

A prominent deficiency of germ-free mice is the lack of expansion of $\mathrm{CD}^{+}{ }^{+}$regulatory $\mathrm{T}$ lymphocytes (Tregs) [95]. This deficiency can be completely restored by the treatment of germ-free mice with polysaccharide A from the capsule of Bacteroides fragilis (see also Figure 5, panel 1) [96-98]. This process is mainly mediated by the pattern recognition receptors (PRRs) of epithelial cells, such as TLRs or Nod-like receptors, receptors which are able to recognize molecules (such as polysaccharide A) produced by intestinal microbes. These mechanisms allow discriminating between beneficial and pathogenic bacteria and increasing the number of immune cells or PRRs [99-101]

B. fragilis is not the only bacterial species that can induce mucosal Tregs; also Roseburia and various Clostridia species as well as others have this capacity $[102,103]$.

In this case the mechanism is totally different. Human colonic bacteria can ferment resistant starch and non-starch polysaccharides (which are major components of dietary fiber) to short-chain fatty acids (SCFAs). Among the SCFAs, butyrate, that has multiple functions including anti-inflammatory properties, is important for a healthy gut physiology $[81,82]$. The SCFAs, in particular butyrate and acetate, can directly promote Treg differentiation in the colon of mice (see also Figure 5, panel 3) [104-106]. The butyrate acts as a transcription factor via histone deacetylase inhibition and also via a $G$ protein-coupled receptor signaling mechanisms [106].

Another example of a commensal bacterium with a direct immunoregulatory function is the segmented filamentous bacterium SFB (see Figure5, panel 2). SFB belongs to a class of anaerobic and clostridia related spore-forming bacteria of the gastrointestinal tract [107]. SFB is closely associated with gut epithelial cells and stimulates these cells to release serum amyloid A1. Colonization of germ-free animals with SFB stimulates maturation of the gut mucosal lymphoid tissue, promotes mucosal IgA production, and stimulates the differentiation of T-helper 17 cells [108].

Akkermansia muciniphila (the single representative of the phylum Verrucomicrobia in the human gut; see Figure 2) is associated with protection against several inflammatory diseases [109,110]. Both the expression of type IV pilias well as production of SCFAs have been proposed as mechanisms of action [111,112]. In patients with Crohn's disease a lower abundance of Faecalibacterium prausnitzii is found [113]. An anti-inflammatory protein from $F$. prausnitzii has been shown to inhibit NF- $\kappa B$ in intestinal epithelial cells and (thus) prevents colitis in an animal model $[114,115]$.

All these examples underscore the importance of gut microbiota on development and function of the (mucosal) immune system. The most compelling evidence for modulation of the immune system by gut microbiota comes from the response to checkpoint inhibition therapy and adoptive cell therapy for cancer [116-122]. Elucidation of the underlying mechanisms and identification of the key microbial species will be the next steps.

\section{Modulation of Intestinal Microbiota by Probiotics and Prebiotics}

The gut microbiota plays a crucial role in the physiological development of both the intestinal as well as the immune system, and therefore disturbances in gut microbiota can be causally related to inflammatory and immune mediated diseases. Indeed, the development of allergic diseases has been linked to an altered gut microbiota composition, reduced microbial exposure and reduced bacterial diversity in childhood [123-125]. This hypothesis has been modified into the 'gut microbial deprivation hypothesis', with its emphasis on alterations of original gut microbiota during infancy [126-130]. Whatever the cause, an aberrant microbial colonization pattern or a distortion of the microbial ecology early in life might predispose the infant to immune mediated diseases such as T-helper 2 (Th2)diseases like allergy, wheezing and asthma, or auto-inflammatory T-helper 1 (Th1) diseases, like inflammatory bowel disease, diabetes and obesity $[75,125,131-135]$. In this context, the window of opportunity for influencing the composition of the intestinal microbiota and possibly modulation ofthe development of (later) allergic or autoimmune diseases, would be the neonatal period.

There is increasing evidence that modulation of the infant microbiota can restore the ecological balance [137-139]. This modulation is mainly done by supplementation of pre- and probiotics. A prebiotic is defined as 'a selectively fermented ingredient that results in specific changes, in the composition and/or activity of the gastrointestinal microbiota, thus conferring benefit(s) upon host health' [140].The term 'probiotic' is used for microorganisms with a health benefit beyond basic nutrition. Probiotics are defined as live microorganisms that, when administered in adequate amounts, confer a health benefit on the host [141]. The most widely used probiotic bacteria belong to either the Lactobacillus or the Bifidobacterium genera. Many studies have investigated the potential of probiotics, both for primary prevention as well as treatment for infectious and/ or immune-mediated diseases. The Cochrane database of systematic reviews list a number of infectious and immune-mediated diseases for which probiotics have shown to have a beneficial effect. These include prevention of Clostridium difficile-associated diarrhea, both in adults as well as in children [142], pediatric antibiotic-associated diarrhea [143], the prevention of acute upper respiratory tract infections [144] and of ventilator associated pneumonia [145], the severity of hepatic encephalopathy [146], the treatment and prevention of pouchitis after ileal pouch-anal anastomosis for chronic ulcerative colitis [147], and prevention of necrotizing enterocolitisin preterm infants [148]. Results obtained with probiotics for primary prevention or treatment of allergic diseases are variable [148-154], which may be related to the strain-specific effects of probiotic bacteria and/ or considerable variations in study design, doses administered and duration of the intervention. In a recent systematic review of diet during pregnancy and infancy and the risk of allergic or autoimmune disease development, a relationship was found between maternal diet during pregnancy and lactation, and eczema or allergic sensitization to food during childhood. A positive health effect was also found for probiotics and supplements of fish oil [155].

Modulation of the (composition and functionality) infant gut microbiota can also be executed by prebiotics. This topic has recently been dealt with in a series of excellent reviews [156-158]. Prebiotics, either alone or in combination with probiotics (the combination of the two is called synbiotics) thus help to develop a healthy gut 
Citation: Rijkers GT, Lindelauf C, Kagenaar W, Rutten NB, van Overveld FJ, et al. (2018) Creation of the World: Regulation of Development of Host Immunity by Microbiota from Birth Onwards. Int J Clin Nutr Diet 4: 132. doi: https://doi.org/10.15344/2456-8171/2018/132

Page 7 of 10

microbiome. Breast milk, containing human milk oligosaccharides, is a natural source of prebiotics and provides the baby with optimal active ingredients for outgrowth of especially bifidobacteria [159].

One of the potential mechanisms by which probiotic bacteria regulate the development of the mucosal immune system is by stimulation of the differentiation of naive $\mathrm{T}$ cells towards Th1 or Treg cells, thereby shifting the balance between Th1 and Th2 cells. There are indications that probiotic intervention, via induction of butyrate production, actually could work this way [160]. Future studies should address host and microbiota interactions and identify optimal timing and duration of pre- and/or probiotic supplementation as strategy for prevention of immune-mediated diseases.

\section{Summary and Conclusion}

To summarize: the human infant develops an initial microbiota as it becomes colonized with a wide variety of microorganisms during or directly after birth. The neonatal period comprises a critical period for its development, when early programming occurs and the immune system matures. The long-term composition and functionality of the newborn's gut microbiome is programmed during this period, thereby laying the foundation for future health and influencing the risk of developing disease later in life [161,162]. The development of the gut microbiota continues during the first years of life and its composition is considered to resemble the adult gastrointestinal tract when the child is at the age of 3 years $[38,163]$. Modulation of the infant microbiota can restore the ecological balance of the microbiota and thus contribute to an optimal development of the immune system, enabling adequate defense against infectious diseases, while avoiding allergic and autoimmune diseases.

\section{Competing Interests}

The authors declare that they have no competing interests.

\section{Author's contributions}

NBR and GTR are responsible for conception and design of the review. All authors contributed to analysis of the literature, writing, and critical reflecting of the manuscript. All authors have seen and approved the final version of the manuscript.

\section{References}

1. Sender R, Fuchs S, Milo R (2016) Revised Estimates for the Number of Human and Bacteria Cells in the Body. PLoS Biol 14: e1002533.

2. Savage DC (1977) Microbial ecology of the gastrointestinal tract. Annu Rev Microbiol 31: 107-133.

3. Vaishampayan PA, Kuehl JV, Froula JL, Morgan JL, Ochman H, et al (2010) Comparative metagenomics and population dynamics of the gut microbiota in mother and infant. Genome Biol Evol 2: 53-66.

4. Lepage $P$, Leclerc $M C$, Joossens $M$, Mondot $S$, Blottière HM, et al. (2013) $A$ metagenomic insight into our gut's microbiome. Gut 62: 146-158.

5. Gill SR, Pop M, Deboy RT, Eckburg PB, Turnbaugh PJ, et al. (2006) Metagenomic analysis of the human distal gut microbiome. Science 312 1355-1359.

6. Bik EM (2009) Composition and function of the human-associated microbiota. Nutr Rev Suppl 2: 164-171.

7. Castanys-Muñoz E, Martin MJ, Vazquez E (2016) Building a Beneficial Microbiome from Birth. Adv Nutr 7: 323-330

8. Hugon P, Dufour JC, Colson P, Fournier PE, Sallah K, et al. (2015) A comprehensive repertoire of prokaryotic species identified in human beings. Lancet Infect Dis 15: 1211-1219.
9. Qin J, Li R, Raes J, Arumugam M, Solvsten K, et al. (2010) A human gut microbial gene catalogue established by metagenomics sequencing. Nature 464: 59-65

10. Fraher MH, O'Toole PW, Quigley EMM (2012) Techniques used to characterize the gut microbiota: a guide for the clinician. Nat Rev Gastroenterol Hepatol 9: 312-322.

11. Zoetendal EG, Rajilic-Stojanovic M, de Vos WM (2008) High-throughput diversity and functionality analysis of the gastrointestinal tract microbiota. Gut 57: 1605-1615.

12. Clemente JC, Ursell LK, Parfrey LW, Knight R (2012) The impact of the gut microbiota on human health: an integrative view. Cell 148: 1258-1270.

13. Blaser MJ (2014) The microbiome revolution. J Clin Invest 124: 4162-4165.

14. Lynch SV, Pedersen $O$ (2016) The Human Intestinal Microbiome in Health and Disease. N Engl J Med 375: 2369-2379.

15. Chen TS, Chen PS (1989) Intestinal autointoxication: a medical leitmotif. J Clin Gastroenterol 11: 434-441.

16. Metchnikoff E (1907) The prolongation of life; optimistic studies. G. P Putnam's Sons, New York \& London.

17. Lederberg J, McCray A (2001) Ome sweet 'omics: A genealogical treasury of words. Science 15: 8

18. Goulet $\mathrm{O}$ (2015) Potential role of the intestinal microbiota in programming health and disease. Nutr Rev Suppl 1: 32-40.

19. Petrosino JF, Highlander S, Luna RA, Gibbs RA, Versalovic J, et al. (2009) Metagenomic pyrosequencing and microbial identification. Clin Chem 55: 856-866

20. Ottman $\mathrm{N}$, Smidt $\mathrm{H}$, de Vos WM, Belzer $\mathrm{C}$ (2012) The function of our microbiota: who is out there and what do they do? Front Cell Infect Microbiol 2: 104

21. Li J, Jia H, Cai X, Zhong H, Feng Q, et al. (2014) An integrated catalog of reference genes in the human gut microbiome. Nat Biotechnol 32: 834-841.

22. MGC Project Team, Temple G, Gerhard DS, Rasooly R, Feingold EA, et al (2009) The completion of the Mammalian Gene Collection (MGC). Genome Res 19: 2324-2333.

23. Woese CR, Fox GE (1977) Phylogenetic structure of the prokaryotic domain: the primary kingdoms. Proc Natl Acad Sci USA 74: 5088-5090.

24. Hattori M, Taylor TD (2009) The human intestinal microbiome: a new frontier of human biology. DNA Res 16: 1-12.

25. Fraher MH, O'Toole PW, Quigley EMM (2012) Techniques used to characterize the gut microbiota: a guide for the clinician. Nat Rev Gastroenterol Hepatol 9: 312-322.

26. Mahowald MA, Rey FE, Seedorf H, Turnbaugh PJ, Fulton RS, et al. (2009) Characterizing a model human gut microbiota composed of members of its two dominant bacterial phyla. Proc Natl Acad Sci USA 106: 5859-5864.

27. Tap J, Mondot S, Levenez F, Pelletier E, Caron C, et al. (2009) Towards the human intestinal microbiota phylogenetic core. Environ Microbiol 11: 2574-2584.

28. Aagaard K, Ma J, Antony KM, Ganu R, Petrosino J, et al. (2014) The placenta harbors a unique microbiome. Sci Transl Med 6: 237 ra65.

29. Collado MC, Rautava S, Aakko J, Isolauri E, Salminen S, et al. (2016) Human gut colonisation may be initiated in utero by distinct microbial communities in the placenta and amniotic fluid. Sci Rep 6: 23129.

30. Ardissone AN, de la Cruz DM, Davis-Richardson AG, Rechcigl KT, Li N, et al. (2014) Meconium microbiome analysis identifies bacteria correlated with premature birth. PLoS One 9: 90784

31. Lauder AP, Roche AM, Sherrill-Mix S, Bailey A, Laughlin AL, et al. (2016) Comparison of placenta samples with contamination controls does not provide evidence for a distinct placenta microbiota. Microbiome 4: 29.

32. Kurokawa K, Itoh T, Kuwahara T, Oshima K, Toh H, et al. (2007) Comparative metagenomics revealed commonly enriched gene sets in human gut microbiomes. DNA Res14: 169-181.

33. Gensollen T, lyer SS, Kasper DL, Blumberg RS (2016) How colonization by microbiota in early life shapes the immune system. Science 352: 539-544.

34. Koenig JE, Spor A, Scalfone N, Fricker AD, Stombaugh J, et al. (2011) Succession of microbial consortia in the developing infant gut microbiome. Proc Natl Acad Sci USA 108: 4578-4585.

35. Palmer C, Bik EM, DiGiulio DB, Relman DA, Brown PO, et al. (2007) Development of the human infant intestinal microbiota. PLoS Biol 5: e177.

Int J Clin Nutr Diet

ISSN: 2456-8171 
Citation: Rijkers GT, Lindelauf C, Kagenaar W, Rutten NB, van Overveld FJ, et al. (2018) Creation of the World: Regulation of Development of Host Immunity by Microbiota from Birth Onwards. Int J Clin Nutr Diet 4: 132. doi: https://doi.org/10.15344/2456-8171/2018/132

Page 8 of 10

36. Bäckhed F, Roswall J, Peng Y, Feng Q, Jia H, et al. (2015) Dynamics and Stabilization of the Human Gut Microbiome during the First Year of Life. Cell Host Microbe 17: 690-703.

37. Ringel-Kulka T, Cheng J, Ringel Y, Salojärvi J, Carroll I, et al. (2013) Intestinal microbiota in healthy U.S. young children and adults-a high throughput microarray analysis. PLoS One 8: e64315.

38. Yatsunenko T, Rey FE, Manary MJ, Trehan I, Dominguez-Bello MG, et al. (2012) Human gut microbiome viewed across age and geography. Nature 486: 222-227.

39. Cheng J, Ringel-Kulka T, Heikamp-de Jong I, Ringel Y, Carroll I, et al. (2016) Discordant temporal development of bacterial phyla and the emergence of core in the fecal microbiota of young children. ISME J 10: 1002-1014.

40. Matamoros S, Gras-Leguen C, Le Vacon F, Potel G, de La Cochetiere MF et al. (2013) Development of intestinal microbiota in infants and its impact on health. Trends Microbiol 21: 167-173.

41. Lozupone CA, Stombaugh JI, Gordon JI, Jansson JK, Knight R, et al. (2012) Diversity, stability and resilience of the human gut microbiota. Nature 489: 220-230.

42. Turnbaugh PJ, Hamady M, Yatsunenko T, Cantarel BL, Duncan A, et al (2009) A core gut microbiome in obese and lean twins. Nature 457: 480484

43. Adlerberth I, Wold AE (2009) Establishment of the gut microbiota in Western infants. Acta Paediatr 98: 229-238.

44. Lloyd-Price J, Abu-Ali G, Huttenhower C (2016) The healthy human microbiome. Genome Med 8: 51.

45. Tamburini S, Shen N, Wu HC, Clemente JC (2016) The microbiome in early life: implications for health outcomes. Nat Med 22:713-722.

46. Penders J, Thijs C, Vink C, Stelma FF, Snijders B, et al. (2006) Factors influencing the composition of the intestinal microbiota in early infancy. Pediatrics 118: 511-521.

47. Arrieta MC, Stiemsma LT, Amenyogbe N, Brown EM, Finlay B, et al. (2014) The Intestinal Microbiome in Early Life: Health and Disease. Front Immuno 5. 427.

48. Madan JC, Hoen AG, Lundgren SN, Farzan SF, Cottingham KL, et al. (2016) Association of Cesarean Delivery and Formula Supplementation With the Intestinal Microbiome of 6-Week-Old Infants. JAMA Pediatr 170: 212-219.

49. Biasucci G, Benenati B, Morelli L, Bessi E, Boehm G, et al. (2008) Cesarean delivery may affect the early biodiversity of intestinal bacteria. J Nutr 138 1796-1800.

50. Mangin I, Suau A, Gotteland M, Brunser O, Pochart P, et al. (2010) Amoxicillin treatment modifies the composition of Bifidobacterium species in infant intestinal microbiota. Anaerobe 16: 433-438.

51. Yassour $M$, Vatanen $T$, Siljander $H$, Hämäläinen $A M$, Härkönen $T$, et al. (2016) Natural history of the infant gut microbiome and impact of antibiotic treatment on bacterial strain diversity and stability. Sci Transl Med 8: 343ra81.

52. Dominguez-Bello MG, Costello EK, Contreras M, et al. (2010) Delivery mode shapes the acquisition and structure of the initial microbiota across multiple body habitats in newborns. Proc Natl Acad Sci USA 107: 11971 11975.

53. Rutayisire E, Huang K, Liu Y, Tao F (2016) The mode of delivery affects the diversity and colonization pattern of the gut microbiota during the first year of infants' life: a systematic review. BMC Gastroenterol 16: 86.

54. Stokholm J, Thorsen J, Chawes BL, Schiørring S, Krogfelt KA, et al. (2016) Cesarean section changes neonatal gut colonization. J Allergy Clin Immunol 138: 881-889.

55. Madan JC, Hoen AG, Lundgren SN, Farzan SF, Cottingham KL, et al. (2016) Association of Cesarean Delivery and Formula Supplementation With the Intestinal Microbiome of 6-Week-Old Infants. JAMA Pediatr 170 212-219.

56. Power SE, O'Toole PW, Stanton C, Ross RP, Fitzgerald GF, et al. (2014) Intestinal microbiota, diet and health. Br J Nutr 111: 387-402.

57. Bezirtzoglou E, Stavropoulou E (2011) Immunology and probiotic impact of the newborn and young children intestinal microflora. Anaerobe 17: 369 374.

58. Jernberg C, Löfmark S, Edlund C, Jansson JK (2007) Long-term ecological impacts of antibiotic administration on the human intestinal microbiota. ISME J 1: 56-66
59. Zou ZH, Liu D, Li HD, Zhu DP, He Y, et al. (2018) Prenatal and postnatal antibiotic exposure influences the gut microbiota of preterm infants in neonatal intensive care units. Ann Clin Microbiol Antimicrob 17: 9.

60. Tanaka S, Kobayashi T, Songjinda P, Tateyama A, Tsubouchi M, et al. (2009) Influence of antibiotic exposure in the early postnatal period on the development of intestinal microbiota. FEMS Immunol Med Microbiol 56: 80-87.

61. Savino F, Roana J, Mandras N, Tarasco V, Locatelli E, et al. (2011) Faecal microbiota in breast-fed infants after antibiotic therapy. Acta Paediatr 100: 75-78.

62. Francino MP (2016) Antibiotics and the Human Gut Microbiome: Dysbioses and Accumulation of Resistances. Front Microbiol 6: 1543.

63. Penders J, Thijs C, van den Brandt PA, Kummeling I, Snijders B, et al.(2007) Gut microbiota composition and development of atopic manifestations in infancy: the KOALA Birth Cohort Study. Gut 56: 661-667.

64. Rutten NB, Rijkers GT, Meijssen CB, Crijns CE, Oudshoorn JH, et al. (2015) Intestinal microbiota composition after antibiotic treatment in early life: the INCA study. BMC Pediatr 15: 204.

65. Oosterloo BC, van Elburg RM, Rutten NB, Bunkers CM, Crijns CE, et al. (2018) Wheezing and infantile colic are associated with neonatal antibiotic treatment. Pediatr Allergy Immunol 29: 151-158.

66. Blaser MJ, Bello MG (2014) Maternal antibiotic use and risk of asthma in offspring. Lancet Respir Med 2: e16.

67. Kemppainen KM, Vehik K, Lynch KF, Larsson HE, Canepa RJ, et al. (2017) Association Between Early-Life Antibiotic Use and the Risk of Islet or Celiac Disease Autoimmunity. JAMA Pediatr 171: 1217-1225.

68. Blaser MJ (2016) Antibiotic use and its consequences for the normal microbiome. Science 352: 544-545.

69. Cox LM, Blaser MJ (2015) Antibiotics in early life and obesity. Nat RevEndocrinol 11: 182-190.

70. Schmidt TSB, Raes J, Bork P (2018) The Human Gut Microbiome: From Association to Modulation. Cell 172: 1198-215.

71. Goodrich JK, Davenport ER, Beaumont M, Jackson MA, Knight R, et al (2016) Genetic Determinants of the Gut Microbiome in UK Twins. Cell Host Microbe 19: 731-743.

72. Xie H, Guo R, Zhong H, Feng Q, Lan Z, et al. (2016) Shotgun Metagenomics of 250 Adult Twins Reveals Genetic and Environmental Impacts on the Gut Microbiome. Cell Syst 3: 572-584.

73. Marietta E, Rishi A, Taneja V (2015) Immunogenetic control of the intestinal microbiota. Immunology 145: 313-322.

74. Chong CYL, Bloomfield FH, O'Sullivan JM (2018) Factors Affecting Gastrointestinal Microbiome Development in Neonates. Nutrients 10: 274.

75. Li M, Wang M, Donovan SM (2014) Early development of the gut microbiome and immune-mediated childhood disorders. SeminReprod Med 32: 74-86.

76. Sjögren YM, Tomicic S, Lundberg A, Böttcher MF, Björkstén B, et al. (2009) Influence of early gut microbiota on the maturation of childhood mucosal and systemic immune responses. Clin Exp Allergy 39: 1842-1851.

77. Indrio F, Martini S, Francavilla R, Corvaglia L, Cristofori F, et al. (2017) Epigenetic Matters: The Link between Early Nutrition, Microbiome, and Long-term Health Development. Front Pediatr 5: 178.

78. Bäckhed F, Ley RE, Sonnenburg JL, Peterson DA, Gordon JI, et al. (2005) Host-bacterial mutualism in the human intestine. Science 307: 1915-1920.

79. Schaible UE, Kaufmann SH (2005) A nutritive view on the host-pathogen interplay. Trends Microbiol 3: 373-380.

80. Feng Q, Chen WD, Wang YD (2018) Gut Microbiota: An Integral Moderator in Health and Disease. Front Microbiol 9: 151.

81. Guilloteau P, Martin L, Eeckhaut V, Ducatelle R, Zabielski R, et al. (2010) From the gut to the peripheral tissues: the multiple effects of butyrate. Nutr Res Rev 23: 366-384.

82. Kasubuchi M, Hasegawa S, Hiramatsu T, Ichimura A, Kimura I, et al. (2015) Dietary gut microbial metabolites, short-chain fatty acids, and host metabolic regulation. Nutrients 7:2839-2849.

83. Rechavi E, Lev A, Lee YN, Simon AJ, Yinon Y, et al. (2015) Timely and spatially regulated maturation of $B$ and $T$ cell repertoire during human fetal development. Science Transl Med 7: 276ra25.

84. Ygberg S, Nilsson A (2012) The developing immune system-from foetus to toddler. Acta Paediatrica 101: 120-127. 
Citation: Rijkers GT, Lindelauf C, Kagenaar W, Rutten NB, van Overveld FJ, et al. (2018) Creation of the World: Regulation of Development of Host Immunity by Microbiota from Birth Onwards. Int J Clin Nutr Diet 4: 132. doi: https://doi.org/10.15344/2456-8171/2018/132

Page 9 of 10

85. Kuper CF, van Bilsen J, Cnossen H, Houben G, Garthoff J, et al. (2016) Development of immune organs and functioning in humans and tes animals: Implications for immune intervention studies. Reprod Toxicol 64: 180-190.

86. Granato A, Chen Y, Wesemann DR (2015) Primary immunoglobulin repertoire development: time and space matter. CurrOpin Immunol 33: 126-131.

87. Brugman S, Perdijk O, van Neerven RJ, Savelkoul HF (2015) Mucosa Immune Development in Early Life: Setting the Stage. Arch Immunol Ther Exp (Warsz) 63: 251-68.

88. Parker A, Lawson MAE, Vaux L, Pin C (2017) Host-microbe interaction in the gastrointestinal tract. Environ Microbiol.

89. Gury-BenAri M, Thaiss CA, Serafini N, Winter DR, Giladi A, et al. (2016) The Spectrum and Regulatory Landscape of Intestinal Innate Lymphoid Cells Are Shaped by the Microbiome. Cell. 166: 1231-1246.

90. Buela KA, Omenetti S, Pizarro TT (2015) Cross-talk between type 3 innate lymphoid cells and the gut microbiota in inflammatory bowel disease. Curr Opin Gastroenterol 31: 449-455.

91. Farkas AM, Ivanov II (2015) Escaping Negative Selection: ILC You in the Gut. Immunity 43:12-14.

92. Hooper LV, Littman DR, Macpherson AJ (2012) Interactions between the microbiota and the immune system. Science 336: 1268-1273.

93. Hug H, Mohajeri MH, La Fata G (2018) Toll-Like Receptors: Regulators of the Immune Response in the Human Gut. Nutrients 10: 203.

94. Menckeberg CL, Hol J, Simons-Oosterhuis Y, Raatgeep HR, de Ruiter LF, et al. (2015) Human buccal epithelium acquires microbial hyporesponsiveness at birth, a role for secretory leukocyte protease inhibitor. Gut 64: 884-893.

95. Tanoue T, Honda K (2012) Induction of Treg cells in the mouse colonic mucosa: a central mechanism to maintain host-microbiota homeostasis. Semin Immunol 24: 50-57.

96. Mazmanian SK, Liu CH, Tzianabos AO, Kasper KL (2005) An immunomodulatorymolecule of symbiotic bacteria directs maturation of the host immune system. Cell 122: 107-118.

97. Mazmanian SK, Round JL, Kasper DL (2008) A microbial symbiosis factor prevents intestinal inflammatory disease. Nature 453: 620-625.

98. Erturk-Hasdemir D, Kasper DL (2018) Finding a needle in a haystack: Bacteroides fragilis polysaccharide $A$ as the archetypical symbiosis factor. Ann N Y Acad Sci 1417: 116-129.

99. Hevia A, Delgado S., Sánchez B, Margolles A (2015) Molecular players involved in the interaction between beneficial bacteria and the immune system. Front Microbiol 6: 1285

100. Fouhy F, Ross RP, Fitzgerald GF, Stanton C, Cotter PD, et al. (2012) Composition of the early intestinal microbiota: Knowledge, knowledge gaps and the use of high throughput sequencing to address these gaps. Landes Bioscience 3: 203-220.

101. Frosali S, Pagliari D, Gambassi G, Landolfi R, Pandolfi F, et al. (2015) How the Intricate Interaction among Toll-Like Receptors, Microbiota, and Intestinal Immunity Can Influence Gastrointestinal Pathology. J Immuno Res 2015: 489821

102. Patterson AM, Mulder IE, Travis AJ, Lan A, Cerf-Bensussan N, et al. (2017) Human Gut Symbiont Roseburia hominis Promotes and Regulates Innate Immunity. Front Immunol 8: 1166

103. Atarashi K, Tanoue T, Oshima K, Suda W, Nagano Y, et al. (2013) Treg induction by a rationally selected mixture of Clostridia strains from the human microbiota. Nature 500: 232-236.

104. Furusawa Y, Obata Y, Fukuda S, Endo TA, Nakato G, et al. (2013) Commensal microbe-derived butyrate induces the differentiation of colonic regulatory T cells. Nature 504: 446-450.

105. Arpaia N, Campbell C, Fan X, Dikiy S, van der Veeken J, et al. (2013) Metabolites produced by commensal bacteria promote peripheral regulatory T-cell generation. Nature 504: 451-455.

106. Kaisar MMM, Pelgrom LR, van der Ham AJ, Yazdanbakhsh M, Everts B, et al. (2017) Butyrate Conditions Human Dendritic Cells to Prime Type Regulatory T Cells via both Histone Deacetylase Inhibition and G ProteinCoupled Receptor 109A Signaling. Front Immunol 8: 1429.

107. Schnupf P, Gaboriau-Routhiau V, Gros M, Friedman R, Moya-Nilges M, et al. (2015) Growth and host interaction of mouse segmented filamentous bacteria in vitro. Nature 520: 99-103.
108. Lin L, Zhang J (2017) Role of intestinal microbiota and metabolites on gut homeostasis and human diseases. BMC Immunol 18: 2 .

109. Hansen CH, Krych L, Nielsen DS, Vogensen FK, Hansen LH, et al. (2012) Early life treatment with vancomycin propagates Akkermansiamuciniphila and reduces diabetes incidence in the NOD mouse. Diabetologia 55: 22852294.

110. Wang L, Christophersen CT, Sorich MJ, Gerber JP, Angley MT, et al. (2011) Low relative abundances of the mucolytic bacterium Akkermansia muciniphila and bifidobacterium spp. in feces of children with autism. Appl Environ Microbiol 77: 6718-6721.

111. Derrien, M, Belzer C, de Vos WM (2016) Akkermansia muciniphila and its role in regulating host functions. MicrobPathog 106: 171-181.

112. Ottman N, Geerlings SY, Aalvink S, de Vos WM, Belzer C, et al. (2017) Action and function of Akkermansia muciniphila in microbiome ecology, health and disease. Best Pract Res Clin Gastroenterol 31: 637-642.

113. Sokol H, Seksik P, Furet JP, Firmesse O, Nion-Larmurier I, et al. (2009) Low counts of Faecalibacterium prausnitzii in colitis microbiota. Inflamm Bowel Dis 15: 1183-1189.

114. Lopez-Siles M, Duncan SH, Garcia-Gil LJ, Martinez-Medina M (2017) Faecalibacterium prausnitzii: from microbiology to diagnostics and prognostics. ISME J 11: 841-851.

115. Quévrain E, Maubert MA, Michon C, Chain F, Marquant R, et al. (2016) Identification of an anti-inflammatory protein from Faecalibacteriumprausnitzii, a commensal bacteriumdeficient in crohn's disease. Gut 65: 415-425

116. Wang Y, Ma R, Liu F, Lee SA, Zhang L, et al. (2018) Modulation of Gut Microbiota: A Novel Paradigm of Enhancing the Efficacy of Programmed Death-1 and Programmed Death Ligand-1 Blockade Therapy. Front Immunol 9: 374.

117. Humphries A, Daud A (2018) The gut microbiota and immune checkpoint inhibitors. Hum Vaccinlmmunother 1:1-14.

118. Uribe-Herranz M, Bittinger K, Rafail S, Guedan S, Pierini S, et al. (2018) Gut microbiota modulates adoptive cell therapy via CD8 $\alpha$ dendritic cells and IL-12. JCl Insight 3: 94952.

119. Cremonesi E, Governa V, Garzon JFG, Mele V, Amicarella F, et al. (2018) Gut microbiota modulate $\mathrm{T}$ cell trafficking into human colorectal cancer. Gut.

120. Hampton T (2018) Gut Microbes May Shape Response to Cancer Immunotherapy. JAMA 319: 430-431.

121. Kroemer G, Zitvogel L (2018) Cancer immunotherapy in 2017: The breakthrough of the microbiota. Nat Rev Immunol 18: 87-88.

122. Kaiser J (2017) Gut microbes shape response to cancer immunotherapy. Science 358: 573.

123. Björkstén B, Sepp E, Julge K, Voor T, Mikelsaar M (2001) Allergy development and the intestinal microflora during the first year of life. $J$ Allergy Clin Immunol108: 516-520.

124. Abrahamsson TR, Jakobsson HE, Andersson AF, Björkstén B, Engstrand L, et al. (2014) Low gut microbiota diversity in early infancy precedes asthma at school age. Clin Exp Allergy 44: 842-850.

125. Bisgaard H, Li N, Bonnelykke K, Chawes BL, Skov T, et al. (2011) Reduced diversity of the intestinal microbiota during infancy is associated with increased risk of allergic disease at school age. J Allergy Clin Immunol 128: 646-652.

126. Wold AE. (1998) The hygiene hypothesis revised: is the rising frequency of allergy due to changes in the intestinal flora? Allergy 53: 20-25.

127. Bae JM (2018) Interpretation of epigenetic epidemiology for allergic diseases. Epidemiol Health.

128. Ferrandiz-Mont D, Wahyuniati N, Chen HJ, Mulyadi M, Zanaria TM, et al. (2018) Hygiene practices: Are they protective factors for eczema symptoms? ImmunInflamm Dis 6: 297-306

129. Haahtela T, Holgate $S$, Pawankar R, Akdis CA, Benjaponpitak $S$, et al. (2013) The biodiversity hypothesis and allergic disease: world allergy organization position statement. World Allergy Organ J 6:3.

130. van Tilburg Bernardes E, Arrieta MC (2017) Hygiene Hypothesis in Asthma Development: Is Hygiene to Blame? Arch Med Res 48: 717-726.

131. Alm B, Erdes L, Möllborg P, Pettersson R, Norvenius SG, et al. (2008) Neonatal antibiotic treatment is a risk factor for early wheezing. Pediatrics 121: $697-702$. 
Citation: Rijkers GT, Lindelauf C, Kagenaar W, Rutten NB, van Overveld FJ, et al. (2018) Creation of the World: Regulation of Development of Host Immunity by Microbiota from Birth Onwards. Int J Clin Nutr Diet 4: 132. doi: https://doi.org/10.15344/2456-8171/2018/132

Page 10 of 10

132. Verhulst SL, Vael C, Beunckens C, Nelen V, Goossens H, et al. (2008) A longitudinal analysis on the association between antibiotic use, intestina microflora, and wheezing during the first year of life. J Asthma 45: 828-832.

133. Kalliomäki M, Collado MC, Salminen S, Isolauri E (2008) Early differences in fecal microbiota composition in children may predict overweight. Am J Clin Nutr 87: 534-538.

134. Reinhardt C, Reigstad CS, Bäckhed F (2009) Intestinal microbiota during infancy and its implications for obesity. J Pediatr Gastroenterol Nutr 48: 249-256.

135. Musso G, Gambino R, Cassader M (2011) Interactions between gut microbiota and host metabolism predisposing to obesity and diabetes. Annu Rev Med 62:361-380.

136. Abraham C, Medzhitov R (2011) Interactions between the hos innate immune system andmicrobes in inflammatory bowel disease. Gastroenterology 140: 1729-1737.

137. Echarri PP, Graciá CM, Berruezo GR, Vives I, Ballesta M, et al. (2011) Assessment of intestinal microbiota of full-term breast-fed infants from two different geographical locations. Early Hum Dev 87: 511-513.

138. Marques TM, Wall R, Ross RP, Fitzgerald GF, Ryan CA, et al. (2010) Programming infant gut microbiota: influence of dietary and environmental factors. CurrOpin Biotechnol 21: 149-156.

139. Markowiak P, Śliżewska K (2017) Effects of Probiotics, Prebiotics, and Synbiotics on Human Health. Nutrients 9: 201.

140. Roberfroid M, Gibson GR, Hoyles L, McCartney AL, Rastall R, et al. (2010) Prebiotic effects: metabolic and health benefits. Br J Nutr 104: 1-63.

141. Hill C, Guarner F, Reid G, Gibson GR, Merenstein DJ, et al. (2014) Expert consensus document: The International Scientific Association for Probiotics and Prebiotics consensus statement on the scope and appropriate use of the term probiotic. Nat Rev Gastroenterol Hepatol 11: 506-514.

142. Goldenberg JZ, Yap C, Lytvyn L, Lo CK, Beardsley J, et al. (2017) Probiotics for the prevention of Clostridium difficile-associated diarrhea in adults and children. Cochrane Database Syst Rev. 12: CD006095.

143. Goldenberg JZ, Lytvyn L, Steurich J, et al. (2011) Probiotics for the prevention of pediatric antibiotic-associated diarrhea. Cochrane Database Syst Rev 19: CD004827.

144. Hao Q, Lu Z, Dong BR, Huang CQ, Wu T, et al. (2015) Probiotics for preventing acute upper respiratory tract infections. Cochrane Database Syst Rev 2:CD006895.

145. Bo L, Li J, Tao T, Bai Y, Ye X, et al. (2014) Probiotics for preventing ventilator-associated pneumonia. Cochrane Database Syst Rev 10: CD009066.

146. Dalal R, McGee RG, Riordan SM, Webster AC (2017) Probiotics for people with hepatic encephalopathy. Cochrane Database Syst Rev 2: CD008716.

147. Singh S, Stroud AM, Holubar SD, Pardi DS (2015) Treatment and prevention of pouchitis after ileal pouch-anal anastomosis for chronic ulcerative colitis. Cochrane Database Syst Rev 16: CD001176.

148. AlFaleh K, Anabrees J (2014) Probiotics for prevention of necrotizing enterocolitisin preterm infants. Cochrane Database Syst Rev 4: CD005496.

149. Ismail IH, Licciardi P V, Tang ML (2013) Probiotic effects in allergic disease. J Paediatr Child Health 49: 709-715.

150. Niers L, Martín R, Rijkers G, Sengers F, Timmerman H, et al. (2009) The effects of selected probiotic strains on the development of eczema (the PandA study). Allergy 64: 1349-1358.

151. Osborn DA, Sinn JKH (2007) Probiotics in infants for prevention of allergic disease and food hypersensitivity. Cochrane Database Syst Rev 4 CD006475.

152. Boyle RJ, Bath-Hextall FJ, Leonardi-Bee J, Murrell DF, Tang ML, et al (2008) Probiotics for treating eczema. Cochrane Database Syst Rev 4 CD006135.

153. Zuccotti G, Meneghin F, Aceti A, Barone G, Callegari ML, et al. (2015) Probiotics for prevention of atopic diseases ininfants: systematic review and meta-analysis. Allergy 70: 1356-1371.

154. West CE (2014) Gut microbiota and allergic disease: new findings CurrOpin Clin NutrMetab Care 17: 261-266.

155. Garcia-Larsen V, lerodiakonou D, Jarrold K, Cunha S, Chivinge J, et al (2018) Diet during pregnancy and infancy and risk of allergic or autoimmune disease: A systematic review and meta-analysis. PLoS Med 15: e1002507.

156. Umu ÖCO, Rudi K, Diep DB (2017) Modulation of the gut microbiota by prebiotic fibres and bacteriocins. MicrobEcol Health Dis. 28: 1348886.
157. Wilson B, Whelan K (2017) Prebiotic inulin-type fructans and galactooligosaccharides: definition, specificity, function, and application in gastrointestinal disorders. J Gastroenterol Hepatol. Suppl 1: 64-68.

158. Deehan EC, Duar RM, Armet AM, Perez-Muñoz ME, Jin M, et al. (2017) Modulation ofthe Gastrointestinal Microbiome with Nondigestible Fermentable Carbohydrates Tolmprove Human Health. Microbiol Spectr.

159. Watkins C, Stanton C, Ryan CA, Ross RP (2017) Microbial Therapeutics Designed for Infant Health. Front Nutr 4: 48.

160. Kim HK, Rutten NB, Besseling-van der Vaart I, Niers LE, Choi YH, et al. (2015) Probiotic supplementation influences faecal short chain fatty acids in infants at high risk for eczema. Benef Microbes 6: 783-790.

161. Barouki R, Gluckman PD, Grandjean P, Hanson M, Heindel JJ, et al. (2012) Developmental origins of non-communicable disease: implications for research and public health. Environ Health 11: 42.

162. Butel MJ, Waligora-Dupriet AJ, Wydau-Dematteis S (2018) The developing gut microbiota and its consequences for health. J Dev Orig Health Dis. Mar 22: 1-8.

163. Subramanian S, Huq S, Yatsunenko T, Haque R, Mahfuz M, et al. (2014) Persistent gut microbiota immaturity in malnourished Bangladeshi children. Nature 510: 417-421.

Int J Clin Nutr Diet

ISSN: $2456-8171$ 